\title{
LIABILITY OF LESSEES AND ASSIGNEES OF COMMERCIAL LEASES IN NEW ZEALAND
}

\author{
Emma Tait*
}

This article concerns the liability of lessees and assignees of commercial leases in New Zealand. This is a complicated area of the law and, as an analysis of the historical context shows, one that was ripe for reform. The Property Law Act project which culminated with the enactment of the Property Law Act 2007 provided an opportunity to undertake this reform. However, this article shows that the resulting Act not only fails to correct existing deficiencies in this area but also places an increased burden on assignees that cannot be justified by reference to privity of contract or privity of estate.

\section{INTRODUCTION}

Commercial leasing transactions are some of the most important transactions that take place in the property market today. Leases usually persist for a lengthy duration and can be worth many millions of dollars so it is important that the obligations of all of the parties involved are clear in law. Unfortunately this certainty has been lacking in New Zealand in recent decades, with the Law Commission describing the law relating to landlords and tenants as "arguably the most deficient area of the [Property Law Act 1952]." 1 These deficiencies were in part a result of the commercial property market crash of the late 1980s which left behind a "legacy of litigation." ${ }^{2}$ Some of the contentious issues arising out of this difficult period have been resolved by the courts but, as this paper will illustrate, uncertainties concerning the liability of both original lessees and assignees remained.

* Submitted as part of the LLB(Hons) programme at Victoria University of Wellington. Recipient of the 2007 Robert Orr McGechan Prize.

1 New Zealand Law Commission The Property Law Act 1952 (NZLC PP16, Wellington, 1991) 9.

2 D Grinlinton and B Sandston "Commercial Leases" (New Zealand Law Society Seminar, Auckland, June 2000). 
The Property Law Act project, which commenced with a preliminary paper in 1991 and culminated with the enactment of the Property Law Act 2007 (PLA 2007), provided an opportunity to address these deficiencies. However, this paper will show that the new legislation fails to achieve this. This will be shown by first analysing the liability of lessees and assignees prior to the enactment of the PLA 2007 to show that reform in this area was necessary. The reform options raised throughout the Property Law Act project will then be compared with the statutory reform that has been undertaken in the United Kingdom. This comparison will demonstrate that the existing problems are unlikely to be adequately addressed by the Property Law Act 2007 and that the Landlord and Tenant (Covenants) Act 1995 (UK) provides an attractive alternative model for reform in these areas.

\section{LIABILITY OF THE ORIGINAL LESSEE PRIOR TO REFORM}

In determining the liability of an original lessee, "[t]he starting point is that at common law an original lessee remains liable on the covenants of the lease throughout the term despite any assignment of it." ${ }^{3}$ This is because a lease is both a contract and a grant of an estate in land. ${ }^{4}$ By entering into a lease, the original lessee enters into a direct contractual relationship with the original lessor and becomes bound by privity of contract. ${ }^{5}$ Privity of contract means that "[t]he original lessee is a person who as principal, undertook towards the lessor, the obligations of the lease for the whole term". ${ }^{6}$ As a result, the original lessee is bound by all of the lease covenants, even if one or both of the original parties assigns their interest in the estate. ${ }^{7}$ "The assignment of the lease does nothing to disturb the direct liability of the lessee to the lessor under the lease for the whole of the term."8

The original lessee is also bound by privity of estate for the period when they are the tenant in possession. At common law, the benefit of covenants by the original lessor which touch and concern the land and the burden of covenants by the original lessee which touch and concern the land run with the term granted by the lease. ${ }^{9}$ The Grantees of Reversion Act 1540 (UK) extended this position by making the benefit of a covenant by the original lessee which touches and concerns the

3 Warnford Investments Ltd v Duckworth [1979] Ch 127, para 3 Megarry V-C.

4 G W Hinde, D W McMorland and P B A Sim Land Law (Butterworths, Wellington, 1978) 546.

5 Ibid, 547.

$6 \quad$ Warnford Investments Ltd v Duckworth, above n 3, para 36 Megarry V-C.

7 Hinde, McMorland and Sim, above n 4, 546.

8 Warnford Investments Ltd v Duckworth, above n 3, para 33 Megarry V-C.

$9 \quad$ Spencer's case (1583) 77 ER 72. 
land run with the reversion, thus allowing an assignee of the reversion to sue the tenant on those covenants. ${ }^{10}$

Privity of estate does not rely on contract; it arises out of the landlord and tenant relationship and binds the parties that are landlord and tenant for the time being. ${ }^{11}$ "The contractual obligations which touch and concern the land having become imprinted on the estate, the tenancy is capable of existence as a species of property independently of the contract." 12 Any subsequent assignee of the term or the reversion will be bound by privity of estate for the period during which they are the landlord or the tenant.

Privity of contract and privity of estate mean that the original lessee is undoubtedly liable on all covenants while they are the tenant in possession. However, the extent of this liability when they assign their interest in the estate can give rise to uncertainties and is an aspect of the law that the Property Law Act project aimed to address.

\section{A Common Law Liability of Original Lessees after an Assignment of the Lease}

1 The early case law

In Baynton v Morgan an intermediate assignee surrendered a portion of the premises to the landlord and a subsequent assignee defaulted on payment of the rent. The lessor successfully recovered the unpaid rent from the original lessee on the basis that they were directly and primarily liable to the landlord. ${ }^{13}$ By assigning the interest in the term the lessee authorised the assignee to exercise all of the lessee's powers. As surrender of part of the premises by the original lessee would not end the term, surrender by the assignee could not have this effect. ${ }^{14}$ "The rule of law is that a lessee remains liable upon his express covenants, notwithstanding an assignment and acceptance by the landlord of rent from the assignee."15

This judgment sits comfortably with the account of privity of contract given above. The original tenant was liable because they had contracted directly with the landlord to observe the covenants of the lease for the duration of the term. As the term had not expired or been surrendered the original tenant was obliged to fulfil his obligations notwithstanding the assignment of the lease.

10 The Grantees of Reversion Act 1540 is in force in New Zealand by virtue of the Imperial Laws Application Act 1988, s 3(1).

11 The Laws of New Zealand (Butterworths, Wellington, 2007) Benefit and Burden of Covenants, para 46(286) (last updated 15 April 2007) www.butterworthsonline.com.

12 City of London Corporation v Fell [1993] QB 589, para 12 Nourse LJ.

13 Baynton v Morgan (1888) 22 QB 74, 82 Lopes LJ.

14 Ibid, 79 Esher LJ.

15 Ibid, 82 Lopes LJ. 


\section{Extending the orthodox position}

The rule of law from Baynton $v$ Morgan was applied in Centrovincial Estates PLC v Bulk Storage Ltd, where a landlord successfully sued the original tenant for rent increased by a deed of variation made between the landlord and an assignee. The original tenant had no knowledge of the variation and it was made in a manner not provided for in the original lease. Nevertheless, based on Baynton $v$ Morgan, Harman J found that: ${ }^{16}$

each assignee is the owner of the whole estate and can deal with it so as to alter it or its terms. The estate

so altered then binds the original tenant, because the assignee has been put into the shoes of the original tenant and can do all such acts as the original tenant could have done.

As a result of this decision, an original lessee could be held liable for a greater burden than that contained in the lease contract. This cannot be justified based on the established understanding of privity of contract. This difficulty was recognised by the New Zealand Law Commission, which stated that "the liability of an assignor for true variations ... is not something which a lay assignor should be expected to anticipate ... the unfairness of continuing liability of this uncommon nature over a long period seems very clear." 17

\section{Friends' Provident Life Office v British Railways Board}

The concerns arising from Centrovincial Estates were put to rest in the United Kingdom by Friends' Provident Life Office v British Railways Board. ${ }^{18}$ In this case both the term of the lease and the reversion had been assigned several times. The intermediate landlord and intermediate assignee varied the lease, increasing the amount of rent due. When a subsequent assignee defaulted the appellant landlord brought a case against the defendant, as original lessee, for the increased rent or, failing that, the original rent. The original lessee argued that the variation equated to a surrender and regrant of the lease, thus releasing them from liability.

The Court held that a variation would amount to a grant of a new lease if it changed the nature of the legal estate by increasing the extent of the premises demised or the length of the term. ${ }^{19}$ As the variation did not have this effect the original lessee remained liable for their obligations under the covenants in the lease.

The Court also found that an original lessee could only be liable for a variation entered into by an assignee if the lease expressly provided for that variation. ${ }^{20}$ In this case the lease did not

16 Centrovincial Estates Plc v Bulk Storage Ltd (1983) 46 P \& CR 393, para 12 (Ch) Harman J.

17 New Zealand Law Commission, above n 1, 146.

19 Ibid, para 43 Beldam LJ.

20 Ibid, para 51 Beldam LJ. 
contemplate the increased rent so the defendant was only liable for the rent due under the original lease.

The Court overturned Centrovincial Estates in this respect because it found that Harman J had misinterpreted the law as stated in Baynton $v$ Morgan. ${ }^{21}$ Baynton $v$ Morgan stands for the proposition that an assignee deals with the tenancy as the owner of the whole estate and as such can deal with it so as to alter its terms. ${ }^{22}$ Harman $\mathrm{J}$ incorrectly surmised from this that the estate so altered would bind the original tenant because the assignee "stands in his shoes". ${ }^{23}$ However, the judges in Baynton $v$ Morgan were not actually required to decided whether a variation by an assignee would bind the original parties; they simply decided that an assignee is put into the position of lessee and can vary the estate by surrendering a part of the premises without such a variation amounting to a regrant of the lease and therefore without affecting the original lessee's liability. ${ }^{24}$

This interpretation of Baynton $v$ Morgan is consistent with the conventional distinction between privity of contract and privity of estate. A lease gives rise to contractual obligations that persist between the original lessor and the original lessee for the duration of the term. However, once the lease is assigned the contractual relationship between the landlord and the original lessee forms no part of the tenurial relationship between the landlord and the current assignee. As such, the contractual obligations of the original lessee cannot be varied by these parties. ${ }^{25}$

4 The New Zealand case law

Friends' Provident Life Office was endorsed by the New Zealand Supreme Court in Wholesale Distributors Limited v Gibbons Holdings Limited. In this case Blanchard J acknowledged the existing uncertainty over whether the original lessee may be liable for a burden that they had never agreed to. ${ }^{26}$ He clarified the law in New Zealand by stating that Friends' Provident Life Office is to be followed. The original lessee will not be liable for any greater burden than contained in the original lease unless the lease expressly provides for such a variation. ${ }^{27}$

The original lessee will also cease to be liable if a variation made after assignment amounts to a surrender and regrant of the lease. This occurs when a variation made by an assignee alters the nature of the legal estate by increasing the extent of the premises demised or the length of the

\footnotetext{
21 Ibid, para 53 Beldam LJ.

22 Ibid, para 54 Beldam LJ.

23 Centrovincial Estates Plc v Bulk Storage Ltd, above n 16, para 18 Harman J.

24 Baynton v Morgan above n 13, 82 Lopes LJ.

25 See City of London Corporation v Fell [1994] 1 AC 458, 603 (HL).

26 Wholesale Distributors Ltd v Gibbons Holdings Ltd (2007) 5 NZ ConvC 194,493, para 12 (SC) Blanchard J.

27 Ibid.
} 
term. ${ }^{28}$ Traditionally, this will occur if the assignee exercises a "renewal" of the lease, but not if they exercise an "extension". 29

In New Zealand the distinction between renewals and extensions has become blurred, with the courts increasingly contrasting a "renewal or extension" with "the grant of a new lease". ${ }^{30}$ Due to the ambiguities inherent in these terms the New Zealand courts look to the "true construction of the respective rights and obligations of the parties as expressed in the relevant documentation." 31 This involves looking for wording such as the "expiry" of the original lease or the "grant" of a new lease. ${ }^{32}$ If the lease is not carefully drafted the original lessee may find that an option unexpectedly operates as an extension rather than a renewal and makes them liable for a longer period than they had anticipated. This is a further example of the uncertainties that existed in this area of the law and adds weight to the argument for reform.

\section{B Liability of Original Lessees under the Property Law Act 1952}

Until recently, the Property Law Act 1952 (PLA 1952) had an important impact on the liability of original lessees in New Zealand. Section 112(1) provided that the benefit of covenants which touch and concern the land runs with the reversionary estate and can be enforced by the person from time to time entitled to the income of the land. ${ }^{33}$ By virtue of this provision an assignee of the reversion could sue the original lessee regardless of whether the breach of covenant occurred before or after the assignment of the reversion. This allowed an assignee of the reversion to sue the original lessee even in circumstances where they had never had a direct legal relationship.

The burden placed on the lessee by this provision was difficult to justify on the basis of privity of contract or privity of estate. Hypothetically, both the lease and the reversion could be transferred several times before these covenants came to be enforced. The original lessee could then be held liable by a landlord with whom they did not contract, based on a breach of covenant by an assignee that they did not choose themselves.

Nevertheless, the New Zealand courts have expressly taken this path. In Paramoor Nine Limited $v$ Pacific Dunlop Holdings (NZ) Limited the Court adopted the reasoning from a line of English cases concerning the interpretation of section 141 of the Law of Property Act 1925 (UK), which is

Friends' Provident Life Office v British Railways Board, above n 18, para 43 Beldam LJ.

Lord Hailsham (ed) Halsbury's Laws of England (4 ed, Butterworths, London, 1994) 27(1) para 467.

Michele Slatter "Renewal of Leases in New Zealand" (1998) 6 APLJ 22, 24.

Sina Holdings Ltd $v$ Westpac Banking Corporation [1996] 1 NZLR 1, 5 (CA) Henry J for the Court.

Slatter, above n 30, 28.

Property Law Act 1952, s 112(1); this section is reproduced in full in the Appendix. 
virtually identical to section 112 of the PLA. ${ }^{34}$ These cases stand for the proposition that once the original lessor has transferred the reversion, the right to recover rent and enforce covenants which touch and concern the land passes to the assignee of the reversion regardless of whether the breach occurred before or after the transfer. ${ }^{35}$

\section{Conclusion on the Liability of an Original Lessee Prior to Reform}

Prior to the recent reform, the burden on the original lessee was exceptionally high as they were contractually liable for the duration of the term of the lease notwithstanding a subsequent assignment by either party. This obligation survived an extension of the term and could be enforced by an assignee of the reversion in the absence of privity of contract or estate. This demonstrates that there was a strong case for taking action to ameliorate the harshness of the existing law. However, before the actions taken are discussed, it is first necessary to consider the liability of an assignee of the lease as they will inevitably play a role in problematic leasing transactions.

\section{LIABILITY OF AN ASSIGNEE OF THE LEASE PRIOR TO REFORM}

At common law the liability of an assignee arises out of privity of estate, which exists only between the current lessor and the current lessee. ${ }^{36}$ A lessor who wants to place continuing liability on an assignee, or who wants to be able to enforce purely personal covenants, must covenant with the assignee directly to establish a contractual link.

In the case of an unregistered lease the liability of an assignee depends on privity of estate; an assignee is not liable for breaches of covenant occurring before the assignment or breaches that occur after the assignee has further assigned the lease. ${ }^{37}$ Privity of estate makes the current landlord and tenant liable for those covenants that touch and concern the land. ${ }^{38}$ At common law it is only those covenants which "touch and concern the land", or "have reference to the subject matter of the lease", ${ }^{39}$ that can be enforced against the assignee of a lease. Covenants which are personal to the

34 Paramoor Nine Ltd v Pacific Dunlop Holdings (NZ) Ltd (1990) 1 NZ ConvC 190,449 (HC) Master Towle.

35 See London \& County (A \& D) Ltd v Wilfred Sportsman Ltd [1970] 2 All ER 600 (CA); Arlesford Trading Co Ltd v Servansingh [1971] 3 All ER 113 (CA); Re King, Robinson v Gray [1963] 1 All ER 781 (CA).

36 Brookers Land Law (Brookers, Wellington, 2001) Assignment of Leases 11.15(06) (last updated 22 August 2007) www.brookersonline.co.nz.

37 Laws of New Zealand, above n 11, Benefit and Burden of Covenants 46(293) (last updated 15 April 2007).

38 Brookers Land Law, above n 36, Assignment of Leases 11.15(06).

39 The phrase "touching and concerning the land" is the traditional phrase and can be traced back to Spencers case, above $\mathrm{n}$ 9. It is synonymous with the phrase "having reference to the subject matter of the lease" which was used in the Property Law Act 1952. 
original parties do not run with the lease when it is assigned. ${ }^{40}$ The question of which covenants meet this test is therefore central to determining the liability of an assignee.

\section{A The Touching and Concerning Test}

There have been many cases over the years concerning whether a covenant can be said to touch and concern the land. ${ }^{41}$ In Hua Chiao Commercial Bank Limited v Chiaphua Industries Limted the Privy Council held that "if it affects the landlord in his normal capacity as landlord or the tenant in his normal capacity as tenant, it may be said to touch and concern the land." 42 Examples of such covenants include the landlord's covenant to repair and the tenant's covenant to pay the rent. ${ }^{43}$

The common law rules for determining what covenants will run with the land are sometimes quite restrictive. ${ }^{44}$ Covenants that appear to bind a future assignee may fail to meet the threshold, such as a covenant requiring the payment of a security deposit, ${ }^{45}$ a covenant preventing environmental remediation being sought, ${ }^{46}$ or an option to purchase the reversionary estate. ${ }^{47}$ This may reflect the historical situation where personal covenants were not allowed to run with the land because a lack of written records made it difficult to ascertain what covenants, outside of the usual or implied covenants, the original parties had entered into. ${ }^{48}$

The role of the touching and concerning test can also be looked at from a Law and Economics perspective by analysing it in terms of efficiency and certainty. The test means that subsequent purchasers will not be burdened by an unexpected personal covenant. It assures purchasers that there

40 Hinde, McMorland and Sim, above n 4, 550.

41 See generally Horsely Estate Ltd v Steiger [1899] 2 QB 79 (CA); Woodall v Clifton [1905] 2 Ch 257 (CA); Hill v Booth [1930] 1 KB 381 (CA); Re Hunter's Lease, Giles v Hutchings [1942] Ch 124 (Ch); Breams Property Investment Co Ltd v Stroulger [1948] 2 KB 1 (CA); P \& A Swift Investments v Combined English Stores Group Plc [1989] AC 632 (HL); Coronation Street Industrial Properties Ltd v Ingall Industries plc [1989] 1 All ER 979 (HL); Harbour Estates Ltd v HSBC Bank plc [2005] Ch 194 (Ch).

42 Hua Chiao Commercial Bank Ltd v Chiaphua Industries Ltd [1987] AC 99 (CA) para 9 Oliver LJ.

43 Hinde, McMorland and Sim, above n 4, 551.

44 Rod Thomas Cross Leases and Unit Titles: Problems and Solutions (New Zealand Law Society, Wellington, 1994) 7.

45 Hua Chiao Commercial Bank Ltd v Chiaphua Industries Ltd, above n 42.

46 Refinery Holding Co v TRMI Holdings Inc (2002) 302 F 3d 343 ( $5^{\text {th }}$ Cir).

47 Woodall $v$ Clifton, above n 41.

48 David Grinlinton, Jane Holland and Ross Mulholland Commercial Leases (New Zealand Law Society Seminar, Wellington, October 2003) 67. 
is a rational relationship between the financial obligations they have undertaken and the benefits to their property. ${ }^{49}$

Preventing personal covenants from running with the land may also reduce inefficient use of the land. ${ }^{50}$ Personal covenants are often highly specific and become obsolete when the interests of the original parties are transferred, whereas arrangements that touch and concern the land are more likely to flow from the natural use of the property. ${ }^{51}$ The test maximises efficiency by "enforcing promises that, absent transaction costs, would have survived successive rounds of bargaining among subsequent generations of owners." 52

Unfortunately the test does not always work as efficiently in practice as the theory would suggest. The established rules have been described as "purely arbitrary", 53 and as the examples given earlier demonstrate, it is not always easy for an assignee to predict whether a covenant will run with the land.

In the case of registered leases the situation is more complex because the land transfer legislation has given rise to fresh uncertainties. Many of the New Zealand cases concerning assignee liability relate to the impact that the Land Transfer Act 1952 (LTA) has on who is liable and under which covenants. ${ }^{54}$

\section{B Land Transfer Act 1952, Section 97(3)}

Transactions concerning the transfer of registered leases are governed by the LTA. Registration of a memorandum of transfer has the effect of passing all the interests of the transferor to the transferee. ${ }^{55}$

Section 97(3) of the LTA provides: ${ }^{56}$

49 Dan A Tarlock "Touch and Concern is Dead, Long Live the Doctrine" (1998) 77 Nebraska L Rev 804, 812.

50 F Parisi and B W F Depoorter Fragmentation of Property Rights: A Functional Interpretation of the Law of Servitudes (Yale Law School Law, Economics and Public Policy Working Paper Series Paper 284, Yale Law School, New Haven, 2003).

51 Ibid.

52 G S Alexander "Freedom, Coercion and the Law of Servitudes" (1998) 73 Cornell L Rev 883, 891.

53 Grant v Edmondson [1931] 1 Ch 1, 28 (CA) Romer LJ.

54 See generally W E Wagener Ltd v Photo Engravers Ltd [1984] 1 NZLR 412 (CA); Seon Developments Ltd v Roger (1993) 2 NZ ConvC 191,664 (CA); Corunna Bay Holdings Ltd v Robert Gracie Dean Ltd [2002] 2 NZLR 186 (CA).

55 Land Transfer Act 1952, s 97(2); this section is reproduced in full in the Appendix.

56 Land Transfer Act 1952, s 97(3); this section is reproduced in full in the Appendix. 
The transferee shall thereupon become subject to and liable for all and every the same requirements and liabilities to which he would have been subject and liable if named in the instrument originally as mortgagee or lessee of the land....

The courts have had considerable difficulty interpreting section 97(3) and its predecessors. In Wilson and King $v$ Brightling the Court considered the meaning of section 69 of the Land Transfer Act 1870, which is essentially identical to section 97(3). The plaintiffs, Wilson and King, were the original lessees; they assigned the lease to the defendant, Brightling. Brightling further assigned the lease and this assignee defaulted. The landlord successfully recovered the unpaid rent from the plaintiffs as original lessees. The plaintiffs then sought to recover this amount from Brightling, contending that section 69 made an assignee not only liable for their own breaches of covenant, but also for breaches by any other assignee.

The Court rejected this interpretation of section 69, instead finding that the provision merely defines the assignee's liability and does not extend it beyond the liability already created at common law. ${ }^{57}$ The provision simply expresses the fact that the assignee is liable on the lessee's covenants as if he had been named as lessee in the lease. This liability ceases when he further assigns the lease. ${ }^{58}$ In New Zealand, the same interpretation has been given to section 97(3) of the LTA, ${ }^{59}$ and it appears to be settled law that this provision does not preserve privity of contract between an assignee and the lessor.

Section 97(3) also has implications for which covenants can be enforced against an assignee. At common law only those covenants which touch and concern the land can be enforced. ${ }^{60}$ However, section 97(3) of the LTA refers to the assignee as being "subject to and liable for all and every the same requirements" as if he had originally been named lessee. ${ }^{61}$ No distinction is drawn between covenants that touch and concern the land and purely personal covenants. On this basis some commentators have argued for a wider interpretation to be given to section 97(3) of the LTA. However, the courts have found that this provision simply restates the common law position and therefore does not make personal covenants binding on assignees. ${ }^{62}$

It has been argued that the common law rules operate too restrictively and could be improved by interpreting section 97(3) to "enable enforcement of any covenant which is intended to bind

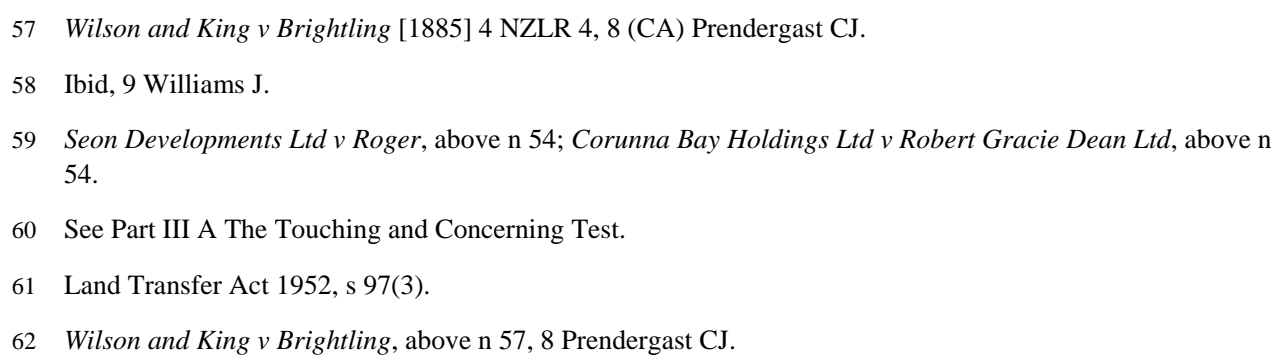


successors in title, but which fails to pass the test for a covenant that runs with the land."63 This would uphold the purpose of the LTA, but might create further uncertainty as the courts grapple with exactly which covenants are intended to bind successors in title.

\section{Land Transfer Act 1952, Section 98}

The interpretation of section 98, which was repealed by the PLA 2007, was even more problematic. ${ }^{64}$ This section provided that: ${ }^{65}$

In every transfer of a lease as aforesaid there shall be implied a covenant by and on the part of the transferee with the transferor that the transferee will thenceforth pay the rent by the said lease reserved, and observe and perform all the covenants in the said lease expressed or implied on the part of the lessee to be observed and performed; and will indemnify and keep harmless the transferor and his representatives from and against all action, suits, claims, and expenses in respect of the non-payment of the said rent, or the breach or non-observance or non-performance of the said covenants or any of them.

The meaning of this section was discussed, but not decided, in Seon Developments Ltd $v$ Roger. In this case, the Rogers were the lessors of a parcel of land that had been assigned to Seon Developments Ltd. Seon further transferred this interest by way of an unsigned sublease that may have operated as an assignment, and the new tenant defaulted. The Rogers successfully obtained judgment against all the previous parties who had directly covenanted with the lessor. Seon had not entered into a direct covenant with the lessor so could not be held liable in this respect. However, Seon remained the registered transferee of the lease and as such was potentially liable under section 97(3) of the LTA. This matter was remitted to the High Court. ${ }^{66}$

Of greater interest is the Court of Appeal's suggestion that Seon, as an intermediate assignee, may have been liable under section 98 of the LTA: ${ }^{67}$

[Section] 98 ... relates expressly to the position as between transferor and transferee of the leasehold estate. It has been suggested [in Hinde, McMorland and Sim Land Law] that it could give rise to a continuing obligation on each transferee to "thenceforth pay the rent ... it is possible that section 98 could be so construed as to impose continuing liability on the transferee of a registered lease."

This statement opened the door to the possibility that section 98 imposed continuing liability of the assignee of a lease to pay the rent. This would have been a departure from the common law position where, in the absence of a direct covenant, an assignee is only bound by privity of estate.

63 Thomas, above n 45, 6.

64 Property Law Act 2007, s 364.

65 Land Transfer Act 1952, s 98.

66 Seon Developments Ltd v Roger (1993) 2 NZ ConvC 191,664 (CA.

67 Ibid, 191,671 Sir Gordon Bisson for the Court, citing Hinde, McMorland and Sim, above n 4, 5.129. 
The basis for putting this contention before the Court was a paragraph in Hinde, McMorland and Sim's Land Law stating that: ${ }^{6}$

it is not settled whether the implied covenant in s 98 imposes a continuing liability, or whether, on analogy of the general law, the transferee is liable only for rent accrued due and breaches of covenant during the time that he is registered proprietor of the lease.

The authors give no further indication as to why the former interpretation is possible or desirable. This meaning would have changed the common law substantially and, in the event of the tenant in possession defaulting, would have allowed the lessor to bring a claim against any previous tenant.

This interpretation could be justified if the implied covenant to "thenceforth pay the rent ... and perform all the covenants" 69 extended for the duration of the term of the lease. However, it seems unlikely that the legislature would have increased the burden on a transferee in this manner without clearly expressing an intention to do so. In Wilson and King $v$ Brightling, the predecessor to section 97(3) of the PLA was interpreted narrowly and held not to preserve privity of contract between an assignee and the landlord because the Court was not willing to infer intention on the part of the legislature to increase assignee liability. Williams $\mathrm{J}$ found that "[he]would want very clear, precise and unmistakeable language on the part of the Legislature to lead the Court to come to th[is] conclusion". ${ }^{70}$ Applying this same logic to section 98, it would not have been appropriate to interpret the provision as imposing continuing liability on an assignee in the absence of plain language to this effect.

It is more likely that section 98 was simply intended to provide an indemnity covenant. This reflects the common law position whereby a person who assigns a lease is entitled to the benefit of an implied indemnity by the assignee. ${ }^{71}$ At common law this indemnity ceases when the assignee further assigns the lease, and is replaced by an indemnity from the new tenant. ${ }^{72}$ The effect of section 98 would have simply been to preserve the chain of indemnity covenants.

\section{Conclusion on the Liability of an Assignee of the Lease Prior to Reform}

At common law a burden will not pass to an assignee unless the covenant in question touches and concerns the land and the assignee is bound by privity of estate or contract. The touching and concerning test is problematic because it produces uncertain results and may exclude covenants that

68 Hinde, McMorland and Sim, above n 4, 555.

69 Land Transfer Act 1952, s 98.

70 Wilson and King $v$ Brightling, above n 57, 9 Williams J.

71 Moule v Garrett (1871-72) LR 7 Ex 101 ER 135 (Ex Chamber).

72 Ibid; Tattle v McKerrow (1902) 20 NZLR 524 (SC); Cashmere v Morris [1993] 3 NZLR 587 (HC). 
the assignee expected to run with the land. Further uncertainties have arisen out of the New Zealand statutory scheme. If section 97(3) of the LTA is given the meaning argued for by some commentators an assignee would instead be liable on all covenants, or at least those that are intended to run with the land. Likewise, if the now repealed section 98 of the LTA had been interpreted in the manner suggested in Seon Developments Limited, an assignee would have had a continuing obligation to pay the rent even if they were no longer bound by privity of contract or privity of estate. This demonstrates the uncertainites that existed in the law prior to the enactment of the PLA 2007 and highlights the areas that could have most benefited from reform.

\section{REFORM IN NEW ZEALAND}

The case law discussed above highlights some of the difficulties that existed in the law relating to landlord and tenant prior to the completion of the Property Law Act Project. This article will now consider how these issues were addressed at each stage of the project in order to draw a conclusion on the appropriateness of the outcome achieved in the PLA 2007. The reform undertaken in the United Kingdom will also be examined and will be shown to be an attractive alternative to the approach taken in the newly enacted New Zealand legislation.

\section{A Preliminary Paper}

In 1991 the Law Commission published a discussion paper on the PLA 1952 and found that it "contains much that is obscure in its language or can be justified, if at all, only by its historical origins." 73 The law relating to leases was described as one of the most deficient areas of the Act, ${ }^{74}$ and several changes were recommended.

\section{The touching and concerning test}

The Law Commission described the distinction between personal covenants and those that touch and concern the land as "arbitrary and illogical." 75 Their preferred option for remedying this problem was to adopt the recommendation of the English Law Commission that "the distinction between lease covenants which touch and concern the land and those which do not should be abolished." 76

The Property Law and Equity Reform Committee (PLERC) had advised against this approach due to concerns about the effect it would have on lease provisions that have nothing to do with the

73 New Zealand Law Commission, above n 1, 6.

74 Ibid, 9.

75 Ibid, 140

76 The Law Commission of England and Wales Landlord and Tenant Law: Privity of Contract and Estate (LC174, Law Commission of England and Wales, London, 1988) 33. 
landlord and tenant relationship. ${ }^{77}$ Nevertheless, the Law Commission felt that abolishing the distinction was desirable, possibly because of the simplicity that it would bring to a notoriously complicated area of the law.

\section{Liability of an assignor of the lease}

The Law Commission also devoted a section of the report to considering the "continuing liability of assignors of leases."78 Although no further explanation of the term "assignors" is given, it appears to refer to the original tenant rather than to an intermediate tenant who has further assigned their interest in the estate.

The Law Commission expressed concern that an assignor may remain liable for many years after the assignment and have no knowledge of the current tenant's identity and no control over the situation. ${ }^{79}$ Based on the rule that emerged from Centrovincial Estates, they were of the view that an assignor can be liable for an increased burden resulting from a variation entered into by an assignee. ${ }^{80}$ This led them to recommend that the law be reformulated so that: ${ }^{81}$

After an assignment a tenant would continue to be liable to the landlord for the performance of the assignee and successors in title to the assignee, but the tenant's liability would be that of a guarantor rather than of a concurrent obligor.

They added that "this would also be the position of an assignee who in turn assigned the lease since, under our proposal, each assignee becomes automatically bound by all covenants." 82 This is a reference back to the recommendation that the distinction between personal covenants and those that touch and concern the land be abolished.

Two comments need to be made about this suggestion. First, the Law Commission made this recommendation out of concern that assignors may become liable for a variation that they had never contemplated. This concern is redundant in light of the decision in Friend's Provident Life Office $v$ British Railways Board. ${ }^{83}$ Secondly, it is not clear why the Law Commission felt that continuing liability would also apply to an assignee who further assigned the lease. The Commission stated that this is the result of their proposal to make each assignee automatically bound by all covenants.

77 Property Law and Equity Reform Commitee Final Report on Legislation Relating to Landlord and Tenant (PLERC, Wellington, 1986) para71.

78 New Zealand Law Commission, above n 1, 145-149.

79 Ibid, 145.

80 Ibid, 146.

81 Ibid, 148.

82 Ibid.

83 Friends' Provident Life Office v British Railways Board, above n 18. 
However, at common law, there are two requirements that must be satisfied before a covenant can be enforced. The first is that the covenant touches and concerns the land and the second is that the party who it is to be enforced against must be bound by privity of contract or estate. ${ }^{84}$ The Law Commission proposal only modifies the first of these factors. The fact that all covenants run with the land does not change the rules relating to which party a covenant can be enforced against. Thus, an intermediate tenant who has not contracted directly with the landlord would liable for all covenants while they are the current tenant, but this liability would end when they further assign their interest in the property and cease to be bound by privity of estate.

\section{B Law Commission Report}

In 1994 the Law Commission took the next step in the Property Law Act project with the publication of Report 29, "A New Property Law Act". Included in this publication was a draft Property Law Bill, sections of which directly address the liability of assignees and original lessees.

\section{The touching and concerning test}

In clauses 192 and 193 of the draft Bill the Law Commission reiterates the proposal that the distinction between personal covenants and those that touch and concern the land be abolished. These proposed sections largely preserved the substance of sections 112 and 113 of the PLA 1952 by making the burden of the lessor's covenants and the benefit of the lessee's covenants run with the reversion. ${ }^{85}$ However, for future leases this was to apply to all covenants, including those of a personal nature, unless otherwise specified in the lease itself. ${ }^{86}$ This the same as the recommendation made in the preliminary paper and the same problems persist.

\section{Liability of an assignor of the lease}

The Law Commission again discussed "the difficulty which can be caused for someone who has assigned a lease and then finds that there remains a continuing and open-ended liability", ${ }^{87}$ and stated that the proposal made in the preliminary paper was too "conservative" in addressing this. ${ }^{88}$ Instead, the Law Commission recommended that an assignor be automatically released from liability five years after the date of assignment. ${ }^{89}$ This five year cap on liability was seen as a

84 Michele Slatter "Who's Liable when a Commercial Lease Falls Over?" (February 1994) New Zealand Business Bulletin 12, 13.

85 New Zealand Law Commission A New Property Law Act (NZLC R29, Wellington, 1994) 158-159. The Draft Bill sections 192 and 193 are reproduced in full in Appendix 3.

86 Ibid, 24

87 Ibid, 9.

88 Ibid

89 Ibid 155-156. The relevant provision in the Draft Bill is section 199, this is reproduced in full in the Appendix. 
suitable compromise between landlord and tenant interests because it "is sufficiently long to protect the legitimate interests of reasonable lessors, who will accept that the liability of an outgoing lessee should not be open-ended." 90 As in the preliminary paper, an assignor would be equated with a guarantor to avoid imposing liability for variations not contemplated by the lease. ${ }^{91}$

\section{The Property Law Act 2007}

The purpose of the PLA 2007 is "to restate, reform and codify (in part) certain aspects of the law relating to real and personal property". 92 Although this Act repeals the Property Law Act 1952, the stated purpose suggests that the PLA 2007 was aimed at tidying up the existing law rather than implementing sweeping reforms. Nevertheless, the PLA 2007 substantially alters the law relating to the liability of an assignee of the lease. First, the distinction between covenants that touch and concern the land and personal covenants is removed for all future leases, ${ }^{93}$ and secondly the PLA 2007 imposes continuing liability on an assignee of the lease. ${ }^{94}$

\section{Assignees liable on all covenants}

The PLA 2007 carries forward the proposal from the earlier papers that the distinction between personal covenants and those which touch and concern the land be abolished. Sections 231 to 233 provide that the burden of every lessor covenant and the benefit of every lessee covenant run with the reversion. ${ }^{95}$ Both sections are qualified by a provision explaining that, for leases coming into operation on or after 1 January 2008, "every covenant" means "every covenant ... whether it refers to the subject matter of the lease or not." 96

As demonstrated above, the existing rules for determining which covenants could be enforced against an assignee required reform. They sometimes operated too restrictively and excluded covenants that were intended to run with the land, ${ }^{97}$ and it was difficult for an assignee to predict which covenants the assignee may be liable on. This is probably why the touching and concerning test had developed a reputation for producing arbitrary results.

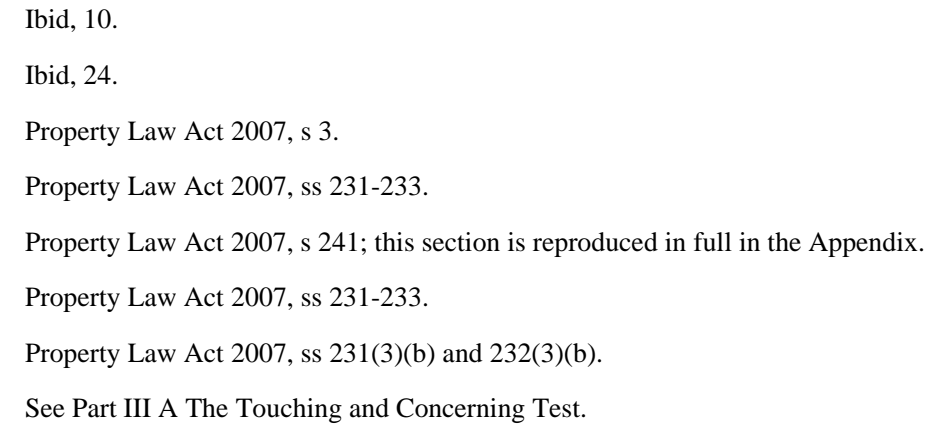


However, there is little point in changing the existing position unless it is replaced with something better. Abolishing the distinction appears to simplify a complex area of the law, but it could cause more problems than it solves. According to practising property lawyers, it is common for modern leases to contain highly specific personal covenants, for example tenants in a shopping mall may be required to belong to a shop owners' association or pay a proportion of their takings as part of the rental. ${ }^{98}$ Having these covenants run with the lease may make the lease more difficult to assign and it may place an unexpected burden on the new assignee.

This problem is mitigated by provisions in each of the relevant sections stating that every covenant runs with the land "unless a contrary intention appears from the lease or from another circumstance." 99 The pitfalls described above can therefore be avoided by taking care to state whether a covenant is personal. However, this will necessitate closer scrutiny of lease provisions and more meticulous drafting. This increases transaction costs and is inefficient, which runs counter to the aim of the touching and concerning rules. ${ }^{100}$

In the case of poorly drafted leases, the courts may be required to determine the intention from the circumstances. How the courts will approach this question remains to be seen, but if the PLA 2007 has the effect of widening the common law test, without encompassing covenants that are clearly intended to be personal, then it will have succeeded in improving the law in this area. However, until a new approach is clearly laid out, there is considerable uncertainty for assignees. This is also inefficient and may put assignees in a vulnerable position.

It is important to note that the PLA 2007 does not completely remove the touching and concerning test from New Zealand law. This test still applies in the case of restrictive covenants, which will run with the servient land in equity if the promise is negative in substance and benefits the dominant land. ${ }^{101}$ When considering the benefit element, "equity adopted the common law rule for the benefit to run with the land, that the covenant must touch and concern the covenantees' land". ${ }^{102}$ In this situation the test remains unaffected by the new provisions.

98 Conversations with practitioners Rod Thomas (Barrister, Auckland) and John Meads (Senior Partner, Kensington Swan, Wellington).

99 Property Law Act 2007, ss 231(2) and 233(2).

100 See Part III A The Touching and Concerning Test.

101 Hinde, McMorland and Sim, above n 4, 1132.

102 Laws of New Zealand, above n 11, Covenants Affecting Freehold Land 6(90). 


\section{Continuing liability for an assignee of the lease}

Part 4, subpart 5 of the PLA 2007 deals with transfers and assignments of leases and applies to any transfer occurring after 1 January 2008. ${ }^{103}$ Within this subpart, section 241 provides: ${ }^{104}$

(1) If there has been a transfer or assignment of a lease, the transferor or assignor remains liable to the lessor for -
(a) the payment of the rent payable under the lease; and
(b) the observance and performance of all covenants of the lessee.

As in the earlier proposals, no definition of "assignor or transferor" is provided. If these terms are given their ordinary meaning then any party that assigns or transfers a lease must be an assignor or transferor, whether they are the original tenant or a subsequent assignee.

\section{Effect of section 241 on original lessees}

In the case of the original tenant, section 241 does not modify the existing position as the original parties to the lease are liable for the entire term due to privity of contract. However, given the concerns raised by the Law Commission about the extent of lessees' liability, ${ }^{105}$ it is surprising that the PLA 2007 does not limit the liability of the original lessee.

The status quo may have been maintained to balance the interests of the landlord and the tenant. A change in the existing position could make it difficult for original lessees to assign the lease as landlords would be reluctant to lose the right to enforce covenants against them. This problem would be exacerbated if the courts expanded the situations in which it is reasonable for a landlord to withhold consent to an assignment. ${ }^{106}$ If, however, the courts retained a narrow view of "reasonable refusal to consent" then any provision releasing a lessee from liability would operate to the detriment of landlords who took care to select a highly creditworthy tenant and now have to accept a less creditworthy, but nevertheless solvent, assignee.

The Law Commission may also have decided against limiting the liability of the original lessee to avoid unfairly prejudicing the lessor, who would remain bound by privity of contract for the remainder of the term. It is settled law that "the contract between the original landlord and the original tenant remains binding on both of them even after the assignment of the lease." 107

\footnotetext{
103 Property Law Act 2007, s 239(1).

104 Property Law Act 2007, s 241(1).

105 See New Zealand Law Commission The Property Law Act 1952 (NZLC PP16, Wellington, 1991) 145-149; New Zealand Law Commission A New Property Law Act (NZLC R29, Wellington, 1994) 9.

106 Property Law Act 2007 s 224 provides that consent to an assignment cannot be unreasonably withheld.

107 Laws of New Zealand, above n 11, Benefit and Burden of Covenants 46(288).
} 
According to City and Metropolitan Properties Ltd v Greycroft, "the landlord's liability to the tenant for existing breaches survives the assignment of the lease in the same way as the tenant's liability to the landlord." 108 It would create an imbalance in the relationship between landlord and tenant if the lessee, upon assignment of the term, was released from liability but the lessor, upon assignment of the reversion, was not.

\section{Effect of section 241 on assignees}

In the case of an assignee of the lease, section 241 represents a major departure from the existing position. It makes an assignee liable for a breach of covenant by a subsequent tenant even when they are not bound by privity of contract or estate. This effectively implements the interpretation of section 98 LTA that was raised in Seon Developments Limited $v$ Roger. ${ }^{109}$ Had that case been decided under the PLA 2007, Seon would clearly have been liable in its capacity as an intermediate assignee.

While this constitutes a substantial change to the existing law, it may have little practical effect on the liability of an assignor or transferor of a lease because it is common commercial practice for landlords to insist on a direct covenant from the assignee. ${ }^{110}$ The standard Deed of Assignment contains a covenant to this effect, ${ }^{111}$ so most assignees would already expect to take on an obligation for the remainder of the term.

However, it is transactions that have not involved standard documentation prepared by solicitors that are most likely to come before the courts. This may be a rare occurrence in the case of commercial leases, but the quantity of litigation on assignee liability is an indication that these situations do arise. Under section 241 the intermediate assignee will be particularly vulnerable. As the Law Commission points out, "[l]ay people who sign a lease as tenant are often under the mistaken belief that their liability to the landlord will cease once they assign the lease". ${ }^{112}$ This is even more likely to be the case when the person in question is only an assignee themselves.

In conclusion, section 241 does not represent a change for the better. Continuing liability for assignees who have not covenanted directly with the landlord cannot be justified on the basis of privity of contract or estate as it imposes liability after these relationships have ceased to exist. Given the prevalence of direct covenants between landlords and assignees, the section also seems

108 City and Metropolitan Properties Ltd v Greycroft Ltd [1987] 3 All ER 839, para 4 (Ch) John Mowbray QC.

109 See Part III C Land Transfer Act 1952, s 98.

110 Brookers Land Law, above n 36, Assignment of Leases 11.15(06).

111 See Auckland District Law Society "Deed of Assignment of Lease" (4 ed, ADLS, Auckland, 2006); Brookers Property Practice and Procedure (Brookers, Wellington, 2001) Deed of Assignment of Lease Lea0.5 (last updated 22 August 2007) www.brookersonline.co.nz.

112 New Zealand Law Commission, above n 1, 145. 
otiose. The only parties who will be caught by it are unsuspecting intermediate tenants who, understandably, assume that their liability ceases when they further assign the lease. The section may be a reflection of common commercial practice, but this is not a good enough reason to impose an unexpected liability on these assignors.

\section{An alternative interpretation}

It is possible to argue for an alternative interpretation of "assignor or transferor" based on the dictum of Williams $\mathrm{J}$ in Wilson and King $v$ Brightling. In that case, a provision making a transferee liable as if originally named as lessee did not impose continuing liability because: ${ }^{113}$

...when the transferee transfers the lease to someone else, the first transferee cannot any longer be said to be in the position of transferee, and, therefore, the liability imposed by the section upon him qua transferee also ceases.

It can therefore be argued that when a lease has been assigned multiple times, only the most recent assignor is in the position of "assignor" as they displace the previous assignor from this role.

However, this interpretation is unlikely to find favour with the courts because it is not compatible with the surrounding sections in the PLA 2007. ${ }^{114}$ For example, section 242 provides that the transferee or assignee will indemnify the transferor or assignor or any previous transferor or assignor against all claims for the non-payment of rent or breach of covenant. ${ }^{115}$ This applies whether the breach is caused by the transferee or assignee or a successor in title of the transferee or assignee. ${ }^{116}$ This clearly shows that a transferor or assignor remains a transferor or assignor notwithstanding a subsequent assignment.

\section{Conclusion}

The enactment of the PLA 2007 has resulted in two substantial changes to the law relating to landlord and tenant. First, all covenants now run with the land unless the lease or the relevant circumstances suggest otherwise. Until it becomes clear how the courts will interpret this provision it is not an improvement on the common law rules as it is still uncertain which covenants will run with the land. There may also be new difficulties if specialised covenants of a personal nature pass to an assignee.

Secondly, the PLA 2007 imposes continuing liability on an assignee of the lease. This reflects standard commercial practice, but is unnecessarily detrimental to assignors who do not covenant

113 Wilson and King v Brightling, above n 58, 9 Williams J.

114 Property Law Act 2004, Part 4, subpart 5; this subpart is reproduced in full in the Appendix.

115 Property Law Act 2007, s 242(1)(c).

116 Property Law Act 2007, s 242(2)(b)(ii). 
directly with the lessor. The traditional understanding of privity of contract was already stretched by statutory provisions allowing an original lessee to be sued by an assignee of the reversion with whom they have never had a contractual relationship. ${ }^{117}$ This new change completely overrides the doctrines of privity of contract and estate and places intermediate tenants in a vulnerable position by exposing them to liability for the duration of the term. This is unfair and, given the pervasiveness of direct covenants, also unnecessary. The approach taken in the United Kingdom is superior in this respect to the New Zealand reform.

\section{REFORM IN THE UNITED KINGDOM}

\section{A Pre-reform}

The bulk of English landlord and tenant law was developed by the courts with little Parliamentary intervention. ${ }^{118}$ In 1986 the Law Commission issued a working paper entitled "Landlord and Tenant: Privity of Contract and Estate: Duration of Liability of Parties to Leases". This paper stated that developments in the commercial property sphere had given rise to a need for reform. For example, landlords were increasingly using commercial property as an investment vehicle and pushing for longer leases with upward-only rent review clauses. ${ }^{119}$ The market recession of the 1980s also made it difficult for a landlord to re-let the property when a tenant defaulted, so landlords would hold on to the lease and bring a claim against the original tenant. ${ }^{120}$ This meant that former tenants who had long ceased to have an interest in the property suddenly faced liability for the actions of a subsequent assignee.

The position of original lessees was made even more precarious by a spate of cases in the early 1980s where the original lessee was held liable for an increased burden due to variations agreed between the landlord and an assignee. ${ }^{121}$ Although this position was reversed in Friend's Provident Life Office, ${ }^{122}$ the concern that it caused was a catalyst for reform.

\section{B The Landlord and Tenant (Covenants) Act 1995 (UK)}

The Landlord and Tenant (Covenants) Act 1995 (UK) (the UK Act) radically changed the law of leases. The two most important changes directly reflect the problems that the PLA 2007 has

117 Property Law Act 1952, s 112.

118 Geoffrey Waterson "The Landlord and Tenant Covenants Act 1995" (1996) 14 Property Management 35, 37.

119 Martin Davey "Privity of Contract and Leases - Reform At Last" (1996) 59 Mod L Rev 78, 81.

120 Waterson, above n 121, 39.

121 See Centrovincial Estates Plc v Bulk Storage Ltd, above n 16; Selous Street Properties Ltd v Oronel Fabrics Ltd (1984) 270 EG 643 (QB).

122 Friends' Provident Life Office v British Railways Board, above n 18. 
attempted to address in New Zealand. First, the UK Act abolished the distinction between personal covenants and those that touch and concern the land. ${ }^{123}$ Secondly, the UK Act addressed the issue of lessee liability by abolishing privity of contract for leases coming into operation after 1 January 1996. ${ }^{124}$

\section{The touching and concerning test}

Under section 3 of the UK Act, all covenants run with the land unless they are "expressed" to be personal. ${ }^{125}$ This appears to narrow the common law concept of a personal covenant by only encompassing those covenants that are actually stated to be personal. ${ }^{126}$ However, in First Penthouse $v$ Channel Hotels and Properties the Court was reluctant to abandon the old distinctions and found that the intention can be expressed explicitly or implicitly. ${ }^{127}$ This is not really an improvement on the traditional touching and concerning test as it does not clarify the law for assignees.

\section{Lessees released from liability}

The UK Act provides that a tenant, whether the original lessee or an assignee, is automatically released from the burden of leasehold covenants when the lease is assigned. ${ }^{128}$ This is tempered by the powers given to landlords to control when a lease can be assigned. A lease may contain an absolute prohibition on assignment or a qualified covenant against assignment. ${ }^{129}$ In the latter case, the lease may specify the circumstances in which consent can be withheld and the landlord will be deemed to be acting reasonably if the agreed terms are adhered to. ${ }^{130}$

It is lawful for the landlord to insist on an Authorised Guarantee Agreement (AGA) as a precondition to giving consent. ${ }^{131}$ An AGA requires the outgoing tenant to act as a guarantor for its

123 Landlord and Tenant (Covenants) Act 1995 (UK), ss 2 and 3.

124 D Knight and L W Durrant "The Law of the Land - the Implications of the Landlord and Tenant (Covenants) Act 1995" (26 July 1995) 92(29) Law Society Gazette 17.

125 Landlord and Tenant (Covenants) Act 1995 (UK), s 3(6)(a).

126 Landlord and Tenant Covenants Act 1995, Part II: Transmission of Leasehold Covenants (2001) 3 Com Prop 563, 569.

127 First Penthouse Ltd v Channel Hotels and Properties (UK) Ltd [2003] EWHC 2713, para 49 (Ch) Lightman J.

128 Martin Dixon Modern Land Law (5 ed, Cavendish Publishing, London, 2005) 230.

129 Ibid.

130 Knight and Durrant, above n 124, 3.

131 Ibid. 
assignee, but not for any subsequent assignee. ${ }^{132}$ Such a guarantee can be extracted only when the lease requires that consent to assignment be obtained, when the lease states that consent may be subject to an AGA and when the tenant guarantees in pursuance of that condition. ${ }^{133}$ This guarantee lapses if the lease is further assigned, ${ }^{134}$ although careful drafting will enable the landlord to extract an AGA from each assignee in turn. ${ }^{135}$

This is an appealing compromise between landlord and tenant interests. The landlord is no longer able to enforce covenants against the original lessee for the duration of the lease, but retains two defendants to any action for a breach: the defaulting tenant and the most recent assignor. The tenant is responsible for their own breaches of covenant, and those of the assignee that they themselves have selected, but ceases to be liable after a further assignment. This is fair because the outgoing tenant is able to select a creditworthy and reliable assignee but has no control over further assignments.

However, in New Zealand this approach was shunned from the outset. As early as 1986 the Property Law and Equity Reform Committee (PLERC) recommended that New Zealand should not adopt the United Kingdom approach. ${ }^{136}$ It preferred the current law where a tenant remained liable if they were bound by privity of contract, either because they are the original lessee or because they covenanted directly with the landlord. The PLERC report felt this balanced the interests of the landlord and the tenant by making it easy for the tenant to assign the lease while also offering protection to a landlord who is required to accept an assignee that they would not necessarily have chosen themselves. ${ }^{137}$ It believed that: ${ }^{138}$

were the law to be changed so that an assignor was released from contingent liability once the assignment was completed, it might become much easier to persuade a court that a landlord should not be obliged to consent to a proposed assignment.

These concerns were carried over into the Law Commission reports. In the Preliminary Paper the Law Commission recommended against an AGA system because the courts might become quick to uphold objections by the landlord to consenting to assignments proposed by both the original lessee and subsequent assignees. An assignee may become locked into a lease because the landlord

132 Landlord and Tenant (Covenants) Act 1995 (UK), s 16.

133 District Judge Stephen Gold "The Civil Way" (1995) 145 New Law Journal 1299, 1301.

134 Landlord and Tenant (Covenants) Act 1995 (UK), s 16.

135 Dixon, above n 128, 236.

136 Property Law and Equity Reform Commitee Final Report on Legislation Relating to Landlord and Tenant (PLERC, Wellington, 1986) para 71.

137 Ibid, para 73.

138 Ibid, para 75. 
is reluctant to allow a further assignment, as to do so under an AGA system would mean losing the benefit of the original tenant's guarantee. The Law Commission also feared that tenants who wished to evade liability could engineer two successive assignments which would secure their release but leave the landlord in vulnerable position. ${ }^{139}$

\section{THE UNITED KINGDOM MODEL AS AN OPTION FOR NEW ZEALAND}

\section{A Abolition of the Touching and Concerning Test}

The UK Act does not offer any improvement over the New Zealand PLA 2007 in terms of removing the distinction between personal covenants and those which touch and concern the land. The New Zealand position is potentially wider because a covenant will not run if "a contrary intention appears from the lease or another circumstance", ${ }^{140}$ whereas under the UK Act only covenants that are "expressed to be personal" do not run with the land. ${ }^{141}$

In both cases, the full impact of the provision will depend on the courts' interpretation of when a covenant is expressed or intended to be personal. The English courts appear to be taking a wide approach to this, ${ }^{142}$ but the New Zealand position remains to be seen. The PLA 2007 has the potential to improve the current law by relaxing the strict common law rules, but it could also create new problems if it causes specialised personal covenants to run with the land. The main problem for lessees and assignees is the uncertainty as to when circumstances will indicate that a covenant does not run. Law and Economics demonstrates the need for efficiency and certainty in the rules determining whether a covenant will run; ${ }^{143}$ this is not achieved by the PLA 2007.

\section{B Release of Lessees from Liability}

In relation to the liability of lessees the UK Act may be a vastly superior to the PLA 2007. Prior to reform in New Zealand, the law placed a substantial burden on original lessees. However, despite the Law Commission's initial concern over the vulnerability of lessees, ${ }^{144}$ the PLA 2007 increases this burden by extending continuing liability to assignees of the lease. This will increase the number of parties in the commercial property market who are at risk of being held liable for a breach of covenant relating to a lease which was assigned many years before. For many businesses such an action could be crippling.

\footnotetext{
139 Law Commission, above n 1, 148.

140 Property Law Act 2007, ss 232-233.

141 Landlord and Tenant (Covenants) Act 1995 (UK), s 3(6).

142 First Penthouse Ltd v Channel Hotels and Properties (UK) Ltd, above n 127, para 49 Lightman J.

143 See Part III A The Touching and Concerning Test.

144 See Part IV Reform in New Zealand.
} 
The UK Act provides an equitable solution to this problem. A lessee is released from liability when they assign the lease, but may be required to act as a guarantor for that assignee. This is fair because the lessee has the prerogative to choose the next tenant and this provides a strong incentive to make a careful selection. It is also fair that this liability should cease when the lease is further assigned because the first tenant has no control over this transaction. The landlord does not suffer as a result of this reform because they are given greater powers to control assignments of the lease. By insisting on an AGA a landlord can ensure that they always have two potential defendants to an action for breach of covenant.

\section{CONCLUSION}

Prior to the Property Law Act project, the law of landlord and tenant was unsatisfactory in several respects. Of particular concern was the liability of original lessees and assignees of a lease. Throughout the Property Law Act project the Law Commission appeared to be advocating measures to reduce lessee liability, but the resulting legislation instead increases liability even further. Abolishing the distinction between personal covenants and those that touch and concern the land does not appear to bring any greater certainty to this area of the law. However, the true effect of this provision will depend on the interpretation given to it by the courts.

Of more concern is the increased liability that falls on assignees of a lease. This does not constitute a major change for parties that follow standard commercial practice because it is usual for assignees to covenant directly with the landlord. However, for assignees who believe they have avoided liability by not entering into a direct contract the spectre of a past lease could be devastating. This increased exposure cannot be justified based on privity of contract or estate and is unfair and unnecessary. The UK Act offers a better model for balancing the interests of the landlord and the tenant and should be seriously considered as an option for further reform in New Zealand. 


\section{APPENDIX}

\section{Property Law Act 1952, ss 112 and 113}

\section{s 112 Rent and benefit of lessee's covenants to run with reversion}

(1) Rent reserved by a lease, and the benefit of every covenant or provision therein having reference to the subject-matter thereof, and on the lessee's part to be observed or performed, and every condition of re-entry and other condition therein, shall be annexed and incident to and shall go with the reversionary estate in the land or in any part thereof immediately expectant on the term granted by the lease, notwithstanding severance of that reversionary estate, and may be recovered, received, enforced, and taken advantage of by the person from time to time entitled, subject to the term, to the income of the whole or any part, as the case may require, of the land leased. This subsection extends to a covenant to do some act relating to the land, notwithstanding that subjectmatter may not be in existence when the covenant is made.

(2) The benefit of every condition of re-entry or forfeiture for a breach of any covenant or condition contained in a lease shall be capable of being enforced and taken advantage of by the person from time to time entitled, subject to the term, to the income of the whole or any part, as the case may require, of the land leased, although that person became, by conveyance or otherwise, so entitled after the condition of re-entry or forfeiture had become enforceable.

(3) This section shall not render enforceable any condition of re-entry or other condition waived or released before that person became entitled as aforesaid.

(4) This section shall apply to leases whether made before or after the commencement of this Act, but with respect only to rent accruing due after the commencement of this Act, and to the benefit of a condition of re-entry or forfeiture for a breach committed after the commencement of this Act of any covenant, condition, or provision contained in the lease.

(5) In the case of leases made before the commencement of this Act, with respect to rent accrued due before the commencement of this Act, and to the benefit of a condition of re-entry or forfeiture for a breach committed before the commencement of this Act of any covenant, condition, or provision contained in the lease, section 88 of the Property Law Act 1908 as in force before the passing of the Property Law Amendment Act 1951 shall continue to apply notwithstanding the repeals hereinafter contained.

(6) This section applies only to leases made on or after the 1st day of January 1906.

\section{s 113 Obligation of lessor's covenants to run with reversion}

(1) The obligation of a covenant entered into by a lessor with reference to the subject-matter of the lease shall, in so far as the lessor has power to bind the reversionary estate immediately expectant on the term granted by the lease, be annexed and incident to and shall go with that reversionary estate or the several parts thereof, notwithstanding severance of that reversionary 
estate, and may be taken advantage of and enforced by the person in whom the term is from time to time vested by conveyance, devolution in law, or otherwise; and, in so far as the lessor has power to bind the person from time to time entitled to that reversionary estate, the obligation aforesaid may be taken advantage of and enforced against any person so entitled.

(2) This section applies only to leases made on or after the 1st day of January 1906

\section{Land Transfer Act 1952, ss 97 and 98}

\section{s 97 Transfer of lease or mortgage}

(1) A registered mortgage or lease may be transferred by memorandum of transfer as aforesaid.

(2) Upon registration of any such memorandum of transfer the estate or interest of the transferor as set forth in the instrument, with all rights, powers, and privileges thereto belonging or appertaining, shall pass to the transferee.

(3) The transferee shall thereupon become subject to and liable for all and every the same requirements and liabilities to which he would have been subject and liable if named in the instrument originally as mortgagee or lessee of the land, estate, or interest; and by virtue of every such transfer as is hereinbefore mentioned the right to sue upon any memorandum of mortgage or other instrument, and to recover any debt, sum of money, annuity, or damages thereunder (notwithstanding that the same may be deemed or held to constitute a chose in action), and all interest in any such debt, sum of money, annuity, or damages shall be transferred so as to vest the same at law as well as in equity in the transferee thereof:

Provided that nothing in this section shall prevent a Court of competent jurisdiction from giving effect to any trusts affecting the said debt, sum of money, annuity, or damages in case the transferee holds the same as a trustee for any other person.

\section{s $98 \quad$ Implied covenants in transfer of lease}

In every transfer of a lease as aforesaid there shall be implied a covenant by and on the part of the transferee with the transferor that the transferee will thenceforth pay the rent by the said lease reserved, and observe and perform all the covenants in the said lease expressed or implied on the part of the lessee to be observed and performed; and will indemnify and keep harmless the transferor and his representatives from and against all action, suits, claims, and expenses in respect of the nonpayment of the said rent, or the breach or non-observance or non-performance of the said covenants or any of them. 


\section{Law Commission Draft Bill, ss 192 and 193}

\section{s 192 Burden of lessor's covenants to run with the reversion}

(1) Where the reversion expectant on a lease of land ceases to be held by the lessor (whether by transfer, assignment, grant, operation of law or otherwise), then, unless a contrary intention appears from the lease or other circumstance, the obligations imposed by every covenant of the lease on the part of the lessor run with the reversion and may be enforced by the person who is from time to time entitled to the leasehold estate or interest against the person who is from time to time entitled to the reversion.

(2) In subsection (1), the reference to every covenant of the lease on the part of the lessor,

(a) in the case of a lease coming into operation before - 199- [the date on which this Act comes into force], is a reference to every covenant on the part of the lessor which has reference to the subject matter of the lease, and,

(b) in the case of a lease coming into operation on or after - 199- [the date on which this Act comes into force], is a reference to every covenant on the part of the lessor, whether or not the covenant has reference to the subject matter of the lease.

s 193 Benefit of lessee's covenants to run with the reversion

(1) This section applies to:

(a) the right to receive the rent payable under a lease;

(b) the right to enforce every covenant of a lease on the part of the lessee, including a covenant relating to a subject-matter not in existence when the covenant was made;

(c) all rights and remedies of the lessor under a lease, including the right to give any notice or to take advantage of any condition or to re-enter or apply for an order for possession, and by so doing to cancel the lease;

(d) the right to enforce any guarantee of the performance of all or any of the covenants of a lease on the part of the lessee.

(2) For the purposes of subsection (1)(b), the reference to every covenant of a lease on the part of the lessee,

(a) in the case of a lease coming into operation before - 199- [date on which this Act comes into force], is a reference to every covenant on the part of the lessee which has reference to the subject-matter of the lease, and,

(b) in the case of a lease coming into operation on or after - 199- [date on which this Act comes into force], is a reference to every covenant on the part of the lessee, whether or not the covenant has reference to the subject-matter of the lease. 
(3) If the reversion expectant on a lease of land ceases to be held by the lessor (whether by transfer, assignment, grant, operation of law or otherwise), then, unless a contrary intention appears from the lease or other circumstance, the rights to which this section applies run with the reversion and may be exercised by the person who is from time to time entitled to the income of the land, whether or not the lessee has acknowledged as lessor the person so entitled (with or without attornment by the lessee).

(4) A person who becomes entitled under subsection (3) to exercise a right to which this section applies

(a) may exercise that right even if it first became exercisable or accrued before the time at which that person became so entitled, unless, before that time, the right was waived or the lessee was released from the obligation to which the right relates, and

(b) is exclusively entitled to exercise that right, unless that person has agreed to the exercise of the right by some other person; and in that case, the right is exercisable by the last-mentioned person to the extent so agreed.

\section{Property Law Act 2007, Part 4 subpart 5}

Subpart 5Effect of transfer or assignment of leases

\section{s 239 Application of subpart}

(1) This subpart applies to a transfer or assignment of a leasehold estate or interest in land that comes into operation on or after 1 January 2008 (whether the lease came into operation before, on, or after that date).

(2) If a transfer or assignment to which this subpart applies relates to part only of the land comprised in a lease, the provisions of this subpart apply only in relation to the part that is transferred or assigned.

s 240 Transferee or assignee becomes lessee

(1) A person who accepts a transfer or assignment of a lease becomes the lessee of the land without need to-

(a) acknowledge (by attornment or otherwise) the lessor as the lessor of the land; or

(b) take possession of the land.

(2) If a lease contains a covenant that the lessee will not, or will not without the lessor's consent, transfer or assign the lease, a transfer or assignment of the lease by the lessee has effect whether or not -

(a) the lessor has consented to the transfer or assignment; and 
(b) the transfer or assignment is in breach of that covenant.

(3) A person who becomes the lessee under this section -

(a) must pay to the lessor the rent payable under the lease; and

(b) must observe and perform all covenants of the lessee; and

(c) may enforce all covenants of the lessor.

(4) Subsection (3) applies whether or not any covenant referred to in that subsection relates to a subject matter that-

(a) was not in existence when the covenant was made; or

(b) refers to the subject matter of the lease.

(5) Subsection (3) does not apply to a covenant that, immediately before the transfer or assignment, was not binding on the lessee, or on the lessor, as the case requires.

(6) To avoid doubt, subsection (2) does not prevent the lessor from

(a) re-entering the land peaceably (and without committing forcible entry under section 91 of the Crimes Act 1961); or

(b) cancelling the lease; or

(c) making a claim for a breach of the covenant referred to in that subsection.

s 241 Transferor or assignor remains liable

(1) If there has been a transfer or assignment of a lease, the transferor or assignor remains liable to the lessor for-

(a) the payment of the rent payable under the lease; and

(b) the observance and performance of all covenants of the lessee.

(2) However, if, without the consent of the transferor or assignor, the transferee or assignee agrees with the lessor to vary the lease, the variation does not increase the liability of the transferor or assignor beyond that provided for by the lease at the time of the transfer or assignment.

(3) Subsection (1) does not apply to a covenant that, immediately before the transfer or assignment, was not binding on the lessee, or on the lessor, as the case requires.

(4) Subsection (2) does not apply if the lease provides for the variation. 


\section{s 242 Covenant implied in transfer or assignment of lease}

(1) Every transfer or assignment of a lease must be taken to contain a covenant by the transferee or assignee with the transferor or assignor that, on and after the date of the transfer or assignment, the transferee or assignee will

(a) pay the rent payable under the lease as and when it falls due; and

(b) observe or perform every other covenant of the lessee; and

(c) indemnify the following persons against all claims and expenses for the non-payment of the rent or the breach of any other covenant of the lessee:

(i) the transferor or assignor and anyone claiming through the transferor or assignor:

(ii) any previous transferor or assignor.

(2) Subsection (1)(c)(ii) applies whether-

(a) the transfer or assignment of the lease by the previous transferor or assignor came into operation before, on, or after 1 January 2008; and

(b) the non-payment of rent or the breach of any other covenant of the lessee results from an act or omission of-

(i) the transferee or assignee; or

(ii) a successor in title of the transferee or assignee. 
